\title{
Keaktifan Indera, Akal, Ingatan, Dan Emosi Atlet Sepakbola Dalam Mengikuti Latihan Di Masa New Normal
}

\author{
Ahmad Atiq ${ }^{1}$, Choirul Umam ${ }^{2}$, Hendri Maksum ${ }^{3}$ \\ ${ }^{123}$ Prodi Pendidikan Jasmani, Universitas Tanjungpura \\ Email : ahmad.atiq@fkip.untan.ac.id ${ }^{1}$,Khoirulumam@gmail.com² ${ }^{2}$ hendrimaksum@gmail.com ${ }^{3}$
}

Menerima: 05 November 2020; Revisi: 13 Februari 2021; Diterima: 21 April 2021

d) https://doi.org/10.24036/MensSana.06012021.17

\begin{abstract}
Identification of problems found during observation, namely 1) During soccer practice, athletes still do not want to interact with their friends. 2) Athletes feel bored in following soccer training because they have to follow several health protocols. 3) When training with the discussion system, athletes are busy joking around with their friends. 4) Lack of desire for athletes to follow coach's instructions. The purpose of this study was to determine the activeness of the senses, active intellect, active memory, and emotional activeness of athletes in participating in soccer training in the new normal period. The method used in this study used a survey research form. Collecting data in this study using a questionnaire. This study uses a Likert scale. The population in this study were all soccer athletes in Pontianak totaling 97 people. The sample used total sampling, amounting to 97 people. The steps of analyzing and processing the data were: editing, classification, tabulation, scale, presenting data, and concluding the results of the study. Based on the results of the study, it can be concluded that the level of activity of athletes in participating in soccer training during the new normal is classified into three classifications, namely very good, good and sufficient. Meanwhile, the overall score grouping of all athletes is classified as good. To increase motivation in practicing football, a coach should make a training design model that is even more attractive so that the athlete is excited and not bored.
\end{abstract}

Keywords: Athletes, Football, Training, New Normal

\section{Abstrak}

Identifikasi masalah yang ditemukan saat observasi yaitu 1) Saat latihan sepak bola berlangsung, atlet masih belum mau berinteraksi dengan temannya. 2) Atlet merasa bosan dalam mengikuti latihan sepak bola karena harus mengikuti beberapa protokol kesehatan. 3) Saat latihan dengan sistem diskusi atlet justru sibuk untuk bergurau dengan temannya. 4) Kurangnya keinginan atlet untuk mau mengikuti instruksi pelatih. Tujuan dari penelitian yaitu untuk mengetahui keaktifan indera, keaktifan akal, keaktifan ingatan, dan keaktifan emosi atlet dalam mengikuti latihan sepak bola di masa new normal. Metode yang digunakan dalam penelitian ini menggunakan bentuk penelitian survei. Pengumpulan data dalam penelitian ini menggunakan angket. Penelitian ini menggunakan skala Likert. Populasi dalam penelitian ini adalah seluruh atlet sepak bola di Pontianak berjumlah 97 orang. Sampel yang digunakan total sampling yang berjumlah 97 orang. Langkah analisis dan mengolah data yaitu: editing, klasifikasi, tabulasi, skala, mempersentasekan data, dan menyimpulkan hasil penelitian. Berdasarkan hasil penelitian dapat disimpulkan bahwa tingkat keaktifan atlet dalam mengikuti latihan sepak bola di masa new normal tergolong pada tiga klasifikasi yaitu sangat baik, baik dan cukup. Sedangkan jumlah pengelompokan skor keseluruhan dari semua atlet termasuk dalam klasifikasi baik. Untuk meningkatkan motivasi dalam berlatih sepakbola sebaiknya seorang pelatih membuat model rancangan latihan yang lebih menarik lagi agar atlet tersebut semangat dan tidak bosan.

Kata Kunci: Atlet, Sepak bola, Latihan, New Normal 


\section{PENDAHULUAN}

Sepak bola adalah olahraga yang sangat banyak diminati oleh masyarakat secara umum dan dapat dengan mudah ditemui (Aji, 2016). Sepak bola merupakan salah satu olahraga yang mendunia, terkenal, dan populer disemua kalangan masyarakat (Ahmad \& Yahmun, 2017). Sepak bola juga mampu memberikan hal-hal yang baik dan indah ketika ada sebuah pertandingan saat berlangsung di siarkan oleh televisi maupun terlihat langsung oleh setiap mata berada di lapangan (Tri Kusuma, 2017).

Sepak bola juga akan menjadi lebih bagus dan kuat apabila didukung dengan adanya faktor keterampilan teknik dasar sepak bola yang bagus (Sinatriyo et al., 2020). Kondisi fisik yang mumpuni, penguatan strategi dan mental juga mampu memberikan dampak yang positif untuk kemajuan sepak bola (Sumarno \& Irianto, 2019).

Sepak bola dapat mempengaruhi dan membantu untuk tujuan peningkatan keilmuan, jasmani dan akhlak, sehingga secara bertahap dapat mengantarkan kepada tujuannya yang paling tinggi (Cendra, 2016). Melalui sepak bola dapat memberikan peranan sangat penting, yaitu memberikan kesempatan kepada atlet untuk terlibat langsung dalam berbagai pengalaman latihan melalui aktivitas jasmani, olahraga dan kesehatan yang terpilih dan dilakukan secara sistematis (Rahman \& Padli, 2020).

Pembekalan pengalaman latihan itu diarahkan untuk membina pertumbuhan fisik dan pengembangan psikis yang lebih baik (Supriyanto, 2017). Sekaligus membentuk pola hidup sehat dan bugar sepanjang hayat (Prastyo et al., 2014).

Namun dimasa pandemi covid-19 atlet sepak bola di Pontianak terpaksa harus libur selama 3 bulan yaitu bulan maret, april dan mei, hal ini mengakibatkan banyak atlet terganggu aktivitas latihannya dan hanya berdiam diri dirumah (Deddy Whinata Kardiyanto, 2020).

Dalam proses pelaksanaannya latihan haruslah tetap melalui protokol kesehatan yang dianjurkan oleh pemerintah daerah Pontianak, meskipun di tengah pandemi khususnya daerah zona hijau diperbolehkan untuk melakukan aktivitas pada umumnya (Tim Komunikasi Publik Gugus Tugas Nasional, 2020). Seperti latihan sepak bola atlet dituntut untuk memiliki keaktifan karena hal tersebut menjadi penentu bagi keberhasilan proses latihan yang dilaksanakan dalam latihan. Keaktifan merupakan salah satu bagian dari tujuan latihan yang harus dicapai
(Ilham Setyawan, 2011).

Keaktifan yang dimaksud adalah atlet aktif bergerak. Pemberian kesempatan latihan gerak melalui keterampilan sepak bola sangatlah penting karena akan berguna untuk perkembangan keterampilan kelak setelah dewasa. Maka dari itu keaktifan digunakan sebagai salah satu aspek penilaian dalam latihan dan tolak ukur dalam keberhasilannya (Ramlah et al., 2014).

Menurut (Nikmah et al., 2016) keaktifan meliputi 1) keaktifan indera yaitu atlet harus dirangsang agar dapat menggunakan alat inderanya sebaik mungkin, 2) keaktifan akal yaitu akal atlet aktif atau diaktifkan untuk memecahkan masalah, 3) keaktifan ingatan yaitu atlet harus aktif menerima jenis latihan yang disampaikan oleh pelatih dan menyimpannya dalam otak, 4) keaktifan emosi yaitu atlet hendaklah senantiasa mencintai latihannya.

Berdasarkan beberapa pendapat di atas dapat disimpulkan bahwa keaktifan dalam proses latihan merupakan parameter-parameter dalam penentuan keberhasilan. Karena keberhasilan dalam suatu proses latihan dapat dilihat dari hasil latihan atlet yang berupa prestasi atau dapat ditentukan dengan melihat keaktifan atlet selama mengikuti proses latihan (Wibowo et al., 2019).

Keaktifan disini tentunya bukan sekedar aktif atau ramai, namun keaktifan yang berkualitas, contohnya saat di lapangan atlet mau berinteraksi ketika latihan berlangsung, atlet mau bertanya dan menjawab pertanyaan, atlet aktif berdiskusi dengan temannya, atlet mau mengikuti instruksi pelatih, aktif dalam bergerak, senang, dan tidak merasa bosan (Muskanan, 2015).

Sedangkan emosi tidak hanya memberi kontribusi terhadap intelegensi, tetapi keseluruhan fungsi kehidupan manusia (Purnamasari et al., 2013). Kecerdasan emosi ini sangat mempengaruhi kehidupan seseorang secara keseluruhan termasuk aktivitas fisiknya. Oleh karena itu, kecerdasan emosional berperan penting juga pada cara seseorang berpikir dan mengingat sesuatu hal yang telah diampaikan sebelumnya.

Dalam hal ini penyampaian seorang pelatih ke atlit. Keterbukaan terhadap emosi mampu menjadikan berfikir efektif dan meningkatkan kecerdasan emosinya (Komarudin \& Risqi, 2020). Prestasi intelektualnya berkembang dan keterampilan geraknya akan maksimal (Supriyanto, 2017). Hal itu dapat memandu atlit untuk mengakui dan menghargai perasaan diri 
sendiri dan orang lain serta menerapkan energi emosi dalam proses latihannya.

Berdasarkan hasil observasi penulis dan wawancara dengan beberapa pelatih dan juga atlit sepak bola di Pontianak pada bulan Juli berjumlah 97 orang yang tersebar di klub Persipon, Panser, dan SMA N 8 Pontianak. mengenai keaktifan atlet dalam mengikuti latihan sepak bola. Peneliti menemukan beberapa masalah dan tertarik untuk melakukan penelitian, adapun masalahnya adalah:

1. Saat latihan sepak bola berlangsung atlet masih belum mau berinteraksi dengan temannya. Seperti belum aktif dalam bergerak.

2. Atlet merasa bosan dalam mengikuti latihan sepak bola karena harus mengikuti beberapa protokol kesehatan.

3. Saat latihan dengan sistem diskusi atlet justru sibuk untuk bergurau dengan temannya. Bahkan saat sesi tanya jawab hanya beberapa atlet yang bertanya dan menjawab pertanyaan.

4. Kurangnya keinginan atlet untuk mau mengikuti instruksi pelatih.

\section{METODE}

Metode yang digunakan dalam penelitian ini adalah penelitian deskriptif dengan pendekatan kuantitatif, sedangkan bentuk penelitian yang digunakan dalam penelitian ini adalah penelitian survei. Adapun populasi dalam penelitian ini adalah seluruh atlet kelas X Sepak bola di Pontianak yang berjumlah 97 yang tersebar di klub Persipon, Panser, dan SMA N 8 Pontianak. Adapun pengumpulan data dalam penelitian ini adalah menggunakan angket (Sugiyono, 2018).

Angket dalam penelitian ini dibuat dan dikembangkan oleh peneliti sendiri dimana angket tersebut disusun dalam bentuk check list yang berjumlah 40 item pernyataan dimana masing-masing item terdapat 4 dimensi didasarkan pada pendapat (Muskanan, 2015) keaktifan meliputi 1.) keaktifan indera, 2) keaktifan akal, 3) keaktifan ingatan, dan 4) keaktifan emosi.

Penelitian ini menggunakan skala Likert. Skala Likert menentukan lokasi kedudukan seseorang dalam suatu kontinum sikap terhadap objek sikap, mulai dari sangat negatif sampai dengan sangat positif (Suharsimi, 2010).

Tabel 1. Pembobotan Jawaban Kuesioner

\begin{tabular}{llcc}
\hline No. & \multicolumn{1}{c}{ Keterangan } & $\begin{array}{c}\text { Skor } \\
\text { Positif }\end{array}$ & $\begin{array}{c}\text { Skor } \\
\text { Negatif }\end{array}$ \\
\hline 1. & Baik Sekali & 5 & 1 \\
\hline 2. & Baik & 4 & 2 \\
\hline 3. & Cukup & 3 & 3 \\
\hline 4. & Kurang Baik & 2 & 4 \\
\hline 5. & Sangat Kurang Baik & 1 & 5 \\
\hline
\end{tabular}

Tabel 2. Kisi-kisi Instrumen

\begin{tabular}{|c|c|c|c|c|}
\hline $\begin{array}{l}\text { Vari } \\
\text { abel }\end{array}$ & Dimensi & Indikator & $\begin{array}{c}\text { Nomor } \\
\text { Soal }\end{array}$ & $\begin{array}{c}\text { Jumlah } \\
\text { Soal }\end{array}$ \\
\hline \multirow[t]{5}{*}{$\begin{array}{l}\text { Keak } \\
\text { tifan }\end{array}$} & Keaktifan Indera & $\begin{array}{l}\text { Atlet dapat } \\
\text { menggunakan } \\
\text { alat inderanya } \\
\text { sebaik } \\
\text { mungkin } \\
\text { yaitu } \\
\text { visualisasi dan } \\
\text { menyimak } \\
\text { penyampaian } \\
\text { dari pelatih }\end{array}$ & $1-10$ & 10 \\
\hline & Keaktifan Akal & $\begin{array}{l}\text { Atlet aktif } \\
\text { dalam } \\
\text { memecahkan } \\
\text { masalah, } \\
\text { mengambil } \\
\text { keputusan, dan } \\
\text { menyusun } \\
\text { pendapat }\end{array}$ & $21-29$ & 9 \\
\hline & $\begin{array}{l}\text { Keaktifan } \\
\text { Ingatan }\end{array}$ & $\begin{array}{l}\text { Atlet aktif } \\
\text { dalam } \\
\text { menerima } \\
\text { jenis latihan } \\
\text { yang } \\
\text { disampaikan } \\
\text { oleh pelatih } \\
\text { dan } \\
\text { menyimpanya } \\
\text { dalam otak }\end{array}$ & $11-20$ & 10 \\
\hline & Keaktifan Emosi & $\begin{array}{l}\text { Senantiasa } \\
\text { mencintai } \\
\text { latihan yang } \\
\text { diadakan } \\
\end{array}$ & $30-40$ & 9 \\
\hline & Total & 40 & & \\
\hline
\end{tabular}

Setelah di uji validitas angket tersebut gugur 2 butir yaitu nomor 39 dan 40. Jadi total angket yang dipakai berjumlah 38 .

Adapun kegiatan-kegiatan yang dilakukan dalam menganalisis dan mengolah data sebagai berikut (Moleong, 2017):

1. Editing yaitu mengecek semua data yang 
dikumpulkan.

2. Klasifikasi yaitu pengelompokan data jawaban-jawaban dari atlet kedalam kategorikategori (skor) yang telah ditentukan sebagaimana tabel 2 berikut ini:

3. Tabulasi yaitu proses pembuatan tabel.

4. Mengklasifikasikan nilai yang diperoleh atlet dalam skala yang telah ditentukan

5. Mempersentasekan data yang telah dihitung perkategorinya dengan rumus.
$D p=\frac{\mathrm{B}}{\mathrm{N}} \times 100 \%$
Dp $=$ deskriptif persentase
$\mathrm{n}=$ jumlah nilai yang diperoleh
$\mathrm{N}=$ jumlah keseluruhan nilai

6. Menyimpulkan hasil penelitian, sehingga diperoleh deskripsi tentang tingkat keaktifan atlet dalam mengikuti latihan sepak bola di masa new normal

\section{HASIL PENELITIAN}

Tabel 3: Klasifikasi Persentase Keaktifan Atlet Dalam Mengikuti Latihan sepak bola

\begin{tabular}{ccc}
\hline Jumlah Skor & Klasifikasi & Persentase \\
\hline $\begin{array}{c}15481,6- \\
18430\end{array}$ & Sangat Baik & $44,3 \%$ \\
\hline $\begin{array}{c}12532,7- \\
15481,5\end{array}$ & Baik & $52,6 \%$ \\
\hline $\begin{array}{c}9583,8- \\
12532,6\end{array}$ & Cukup & $3,1 \%$ \\
\hline $6634,9-9583,7$ & Kurang & $0 \%$ \\
\hline $3686-6634,8$ & $\begin{array}{c}\text { Kurang } \\
\text { sekali }\end{array}$ & $0 \%$ \\
\hline
\end{tabular}

Merujuk pada tabel di atas, atlet Sepak bola di Pontianak tergolong pada tiga kategori yaitu sangat baik, baik dan cukup. Sedangkan untuk jumlah skor pengelompokan semua atlet adalah 15070 yang berarti keaktifan dalam mengikuti latihan sepak bola di Pontianak semua atlet termasuk dalam kategori baik.

Pada tabel di atas, bahwa perbandingan antara atlet dengan kategori baik lebih tinggi dibanding kategori sangat baik dan cukup selisihnya sebesar $5,2 \%$. Atlet yang termasuk dalam kategori sangat baik adalah sebesar 44,3\%, atlet yang termasuk dalam kategori baik jumlahnya lebih besar yaitu $52,6 \%$, sedangkan yang termasuk dalam kategori cukup yaitu sebesar 3,1\%. Untuk atlet yang termasuk dalam kategori kurang dan kurang sekali berjumlah $0 \%$.

\section{Deskriptif Data Keaktifan Indra.}

Berdasarkan dari data hasil penelitian yang telah dilaksanakan dapat dijabarkan mengenai keaktifan indra atlet sepak bola di Pontianak. Sebagaimana tabel 4 di bawah ini:

Tabel 4 : Kategori Keaktifan Indra

\begin{tabular}{ccc}
\hline Jumlah Skor & Klasifikasi & Persentase \\
\hline $42,4-50$ & Sangat Baik & $20 \%$ \\
\hline $34,3-42,3$ & Baik & $55 \%$ \\
\hline $26,2-34,2$ & Cukup & $24 \%$ \\
\hline $18,1-26,1$ & Kurang & $1 \%$ \\
\hline $10-18$ & Kurang sekali & $0 \%$ \\
\hline
\end{tabular}

Hasil dari tabel penelitian mengenai keaktifan indra atlet, dapat dipaparkan bahwa atlet Sepak bola di Pontianak tergolong pada empat kategori yaitu sangat baik, baik, cukup dan kategori kurang. Kategori sangat baik sebesar $20 \%$, baik sebesar $55 \%$, cukup sebesar $24 \%$, dan kurang sebesar $1 \%$. Perbedaan kategori antara sangat baik dan baik yaitu sebesar 35\%. Sedangkan kategori cukup dan kurang mempunyai selisih sebesar 23\%. Untuk kategori kurang sekali tidak ada ataupun $0 \%$.

\section{Deskriptif Data Keaktifan Ingatan.}

Adapun data yang diperoleh mengenai keaktifan ingatan dari hasil penelitian yang telah dilaksanakan dapat dilihat pada tabel 5 di bawah ini:

Tabel 5: Kategori Keaktifan Ingatan

\begin{tabular}{lll}
\hline Jumlah Skor & Klasifikasi & Persentase \\
\hline $42,4-50$ & Sangat Baik & $50,5 \%$ \\
\hline $34,3-42,3$ & Baik & $40,2 \%$ \\
\hline $26,2-34,2$ & Cukup & $9,3 \%$ \\
\hline $18,1-26,1$ & Kurang & $0 \%$ \\
\hline $10-18$ & Kurang sekali & $0 \%$ \\
\hline
\end{tabular}

Hasil data pada tabel di atas, menjelaskan bahwa keaktifan ingatan atlet Sepak bola di Pontianak tergolong pada tiga kategori yaitu kategori sangat baik, baik dan cukup. Kategori sangat baik mempunyai persentase sebesar $50,5 \%$, kategori baik sebesar $40,2 \%$ dan kategori cukup 9,3\%. Sedangkan untuk kategori kurang dan kurang sekali yaitu sebesar $0 \%$.

\section{Deskriptif Data Keaktifan Akal.}

Sesuai dengan data penelitian dapat dijabarkan mengenai keaktifan akal atlet Sepak bola di Pontianak dilihat pada tabel 6 di bawah ini:

Tabel 6: Kategori Keaktifan Akal

\begin{tabular}{lll}
\hline Jumlah Skor & Klasifikasi & Persentase \\
\hline $38,2-45$ & Sangat Baik & $9,3 \%$ \\
\hline $30,9-38,1$ & Baik & $55,7 \%$ \\
\hline $23,6-30,8$ & Cukup & $32 \%$ \\
\hline $16,3-23,5$ & Kurang & $3 \%$ \\
\hline
\end{tabular}


$9-16,2$

Kurang sekali $\quad 0 \%$

Berdasarkan hasil data yang diperoleh diketahui bahwa atlet Sepak bola di Pontianak tergolong pada empat kategori yaitu kategori sangat baik, baik, cukup dan kurang. Kategori sangat baik memiliki persentase sebesar 9,3\%, baik sebesar 55,7\%, cukup sebesar $32 \%$ dan kurang dengan persentase sebesar 3\%. Sedangkan untuk kategori kurang sekali sebesar $0 \%$.

\section{Deskriptif Data Keaktifan Emosi.}

Sesuai dengan data penelitian dapat dijabarkan mengenai keaktifan emosi atlet Sepak bola di Pontianak dilihat pada tabel 7 di bawah ini:

Tabel 7: Kategori Keaktifan Emosi

\begin{tabular}{lll}
\hline Jumlah Skor & Klasifikasi & Persentase \\
\hline $38,2-45$ & Sangat Baik & $51,2 \%$ \\
\hline $30,9-38,1$ & Baik & $81,4 \%$ \\
\hline $23,6-30,8$ & Cukup & $13,4 \%$ \\
\hline $16,3-23,5$ & Kurang & $0 \%$ \\
\hline $9-16,2$ & Kurang sekali & $0 \%$ \\
\hline
\end{tabular}

Berdasarkan hasil data yang diperoleh mengenai keaktifan emosi, diketahui bahwa atlet sepakbola di Pontianak tergolong pada tiga kategori yaitu kategori sangat baik, baik, dan cukup. Kategori sangat baik memeiliki persentase sebesar $51,2 \%$, baik sebesar $81,4 \%$, dan cukup dengan persentase sebesar $13,4 \%$. Sedangkan untuk kategori kurang dan kurang sekali sebesar $0 \%$.

\section{PEMBAHASAN}

\section{Keaktifan Indra Atlet}

Sesuai dengan data yang ada pada tabel 4 mengenai keaktifan indra dapat dipaparkan bahwa atlet sepak bola Pontianak di masa new normal tergolong pada empat kategori yaitu sangat baik yaitu sebesar $20 \%$, baik sebesar $55 \%$, cukup sebesar $24 \%$ dan kurang sebesar $1 \%$. Data ini menunjukkan bahwa keaktifan indra atlet sepak bola Pontianak dalam mengikuti latihan sepak bola di masa new normal memiliki perbedaan yang signifikan sehingga masih tergolong lemah.

Jumlah atlet yang tergolong dalam kategori sangat baik sebanyak 19 atlet atau sebesar $20 \%$. Hasil ini menunjukkan bahwa ketika dalam mengikuti latihan sepak bola atlet sudah menunjukkan dan sudah dapat menggunakan alat inderanya dengan sebaik mungkin yaitu visualisasi saat berlatih sudah bagus dan atlet dapat menyimak penyampaian dari pelatih.

Atlet yang termasuk dalam klasifikasi baik yaitu sebesar 55\% atau sebanyak 53 atlet. Hasil ini menunjukkan bahwa ketika saat mengikuti latihan sepak bola di masa new normal atlet sudah menampakkan hasil yang baik, namun masih terdapat atlet yang belum sungguh-sungguh.

Klasifikasi kategori cukup yaitu sebesar $24 \%$ atau sebanyak 23 atlet. Hasil ini menunjukkan bahwa dalam mengikuti latihan sepak bola atlet sudah mempunyai keaktifan indra yang memadai. Sedangkan klasifikasi kategori kurang yaitu sebesar $1 \%$ atau sebanyak 2 atlet. Hasil ini menunjukkan bahwa dalam mengikuti latihan sepak bola terdapat 2 atlet yang belum mencapai kriteria. Meskipun hanya 2 atlet yang belum mencapai kriteria tentu data ini dapat menjadi pertimbangan kepada atlet untuk dapat meningkatkan lagi keaktifan indranya seperti memvisualisasikan situasi saat latihan dan serius mendengarkan penjelasan dari pelatih.

Atlet yang termasuk klasifikasi kurang sekali yaitu $0 \%$. Artinya tidak ada atlet yang termasuk dalam pengelompokkan klasifikasi ini, sehingga dapat dikatakan keaktifan indra atlet dalam mengikuti latihan sepak bola di masa new normal sudah tidak perlu lagi diragukan.

\section{Keaktifan Ingatan Atlet.}

Mengenai keaktifan ingatan atlet dapat dipaparkan bahwa atlet sepak bola Pontianak di masa new normal tergolong pada 3 kategori yaitu sangat baik, baik dan cukup. Kategori sangat baik sebesar $50,5 \%$, baik sebesar $40,2 \%$ dan cukup sebesar 9,3\%. Sedangkan untuk kategori kurang dan kurang sekali sebesar yaitu $0 \%$.

Atlet yang termasuk dalam kategori sangat baik sebesar $50,5 \%$ atau sebanyak 49 atlet menunjukkan bahwa keaktifan ingatan dalam mengikuti latihan sepak bola di masa new normal, atlet sudah memiliki keaktifan ingatan yang sesuai dengan kriteria.

Klasifikasi baik pada keaktifan ingatan sebesar 40,2\% atau sebanyak 39 atlet. Hasil ini menunjukkan bahwa keaktifan ingatan atlet dalam mengikuti latihan sepak bola di masa new normal sudah baik dan seharusnya tetap dipertahankan.

Sedangkan klasifikasi kategori cukup yaitu sebesar $9,3 \%$ atau sebanyak 9 atlet. Ini menunjukkan bahwa keaktifan ingatan atlet dalam mengikuti latihan sepak bola di masa new normal 
belum mencapai kriteria maksimal dan atlet tetap harus selalu memperhatikan aspek-aspek yang menyangkut keaktifan ingatan seperti dapat dengan mudah menerima jenis latihan yang disampaikan oleh pelatih dan menyimpannya dalam otak.

Tidak terdapat atlet yang berada dalam kategori kurang dan kurang sekali, tentu saja ini membuktikan bahwa keaktifan ingatan atlet dalam mengikuti latihan sepak bola di masa new normal tidak perlu diragukan lagi.

\section{Keaktifan Akal Atlet.}

Mengenai keaktifan akal atlet dapat dipaparkan bahwa atlet sepak bola Pontianak di masa new normal tergolong pada 4 kategori yaitu kategori sangat baik, baik, cukup dan kurang. Kategori sangat baik sebesar 9,3\%, baik sebesar $55,7 \%$, cukup sebesar $32 \%$ dan kurang sebesar $3 \%$. Sedangkan untuk kategori kurang sekali sebesar yaitu $0 \%$.

Atlet yang termasuk dalam kategori sangat baik sebesar $9,3 \%$ atau sebanyak 9 atlet. Hasil ini menunjukkan bahwa keaktifan akal dalam mengikuti latihan sepak bola di masa new normal atlet sudah memiliki keaktifan akal yang sesuai dengan kriteria.

Atlet yang termasuk klasifikasi baik pada keaktifan akal sebesar 55,7\% atau sebanyak 54 atlet. Hasil ini menunjukkan bahwa keaktifan akal atlet dalam mengikuti latihan sepak bola di masa new normal sudah baik.

Sedangkan atlet yang termasuk klasifikasi kategori cukup yaitu sebesar 32\% atau sebanyak 31 atlet. Hasil Ini menunjukkan bahwa keaktifan akal atlet dalam mengikuti latihan sepak bola di masa new normal sudah memadai. Kategori kurang dengan persentase sebesar 3\% atau sebanyak 3 atlet menandakan bahwa masih terdapat atlet yang belum memenuhi kriteria maksimal sehingga masih tergolong kategori yang sangat rendah dan belum memadai. Oleh karena itu atlet tetap harus selalu memperhatikan aspekaspek seperti aktif dalam memecahkan masalah, mengambil keputusan, dan menyusun pendapat.

Tidak terdapat atlet yang berada dalam kategori kurang sekali, tentu saja ini membuktikan bahwa keaktifan akal atlet dalam mengikuti latihan sepak bola di masa new normal tidak perlu diragukan lagi.

\section{Keaktifan Emosi Atlet.}

Keaktifan emosi atlet sepak bola Pontianak di masa new normal tergolong pada 3 kategori yaitu kategori sangat baik, baik, dan cukup. Kategori sangat baik sebesar $51,2 \%$, baik sebesar $81,4 \%$, cukup sebesar $13,4 \%$. Sedangkan untuk kategori kurang dan kurang sekali tidak ada atau sebesar $0 \%$.

Atlet yang termasuk dalam kategori sangat baik sebesar $51,2 \%$ atau sebanyak 5 atlet. Hasil ini menunjukkan bahwa keaktifan emosi atlet masih belum maksimal mengingat hanya sebanyak 5 atlet yang termasuk kategori sangat baik .

Atlet yang termasuk klasifikasi baik pada keaktifan emosi sebesar $81,4 \%$ atau sebanyak 79 atlet. Hasil ini menunjukkan bahwa keaktifan emosi atlet dalam mengikuti latihan sepak bola di masa new normal sudah baik ditandai dengan adanya peningkatan persentase sebesar 30,2\% dan dengan bertambahnya jumlah atlet sebanyak 79 atlet tentu hasil ini sudah sangat bagus dan termasuk kedalam kriteria maksimal.

Sedangkan atlet yang termasuk klasifikasi kategori cukup yaitu sebesar $13,4 \%$ atau sebanyak 13 atlet. Hasil Ini menunjukkan bahwa keaktifan emosi atlet dalam mengikuti latihan sepak bola di masa new normal sudah memadai. Sehingga menandakan bahwa masih terdapat atlet yang belum memenuhi kriteria maksimal sehingga masih tergolong kategori yang sangat rendah dan belum memadai. Oleh karena itu atlet harus menanamkan rasa senang saat mengikuti latihan sepak bola di masa new normal dan senantiasa mencintai latihan sepak bola.

Tidak terdapat atlet yang berada dalam kategori kurang dan kurang sekali pada klasifikasi keaktifan emosi pada atlet sepak bola Pontianak di masa new normal, tentu saja ini membuktikan bahwa keaktifan emosi atlet dalam mengikuti latihan sepak bola Pontianak di masa new normal tidak perlu diragukan lagi.

Penelitian yang elean dengan penelitian ini adalah penelitian yang dilakukan oleh (Effendi, 2016) tentang psikologi yang diterapkan dalam bidang olahraga. Meliputi faktor-faktor yang berpengatuh secara langsung terhadap atlet dan faktor-faktor di luar atlet yang dapat mempengaruhi penampilan (performance) atlet tersebut.

Di dalam pembinaan olahraga, aspek psikologis merupakan salah satu faktor yang mempengaruhi keberhasilan tercapainya suatu prestasi. Faktor psikologi dan tingkah laku meliputi; motif-motif berprestasi, intelegensi, aktualisasi diri, kemandirian, agresivitas, emosi, percaya diri, motivasi, semangat, rasa 
tanggungjawab, rasa sosial, hasrat ingin menang dan sebagainya.

Psikologi olahraga sangat penting di dalam pembinaan olahraga prestasi. Beberapa manfaat psikologi olahraga dalam meningkatkan prestasi atlet yaitu dapat menjelaskan dan memahami tingkahlaku atlet dan gejala-gejala psikologik yang terjadi dalam olahraga pada umumnya, dapat meramalkan atau membuat prediksi dengan tepat kemungkinan-kemungkinan yang dapat terjadi pada atlet. Berkaitan dengan permasalahan psikologik, dan dapat mengontrol dan mengendalikan gejala tingkah laku dalam olahraga. Dengan perlakuan-perlakuan untuk menanggulangi hal-hal yang kurang menguntungkan, juga dapat memberi perlakuanperlakuan untuk mengembangkan kemampuan dan segi-segi positif yang dimiliki atlet.

\section{KESIMPULAN}

Adapun kesimpulan penelitian mengenai keaktifan atlet dalam mengikuti latihan sepak bola, maka dapat disimpulkan bahwa:

1. Keaktifan indra, atlet sepak bola Pontianak di masa new normal tergolong pada empat kategori yaitu sangat baik sebesar $20 \%$, baik sebesar 55\%, cukup sebesar $24 \%$, dan kurang sebesar 1\%. Sedangkan kategori kurang sekali tidak ada ataupun $0 \%$.

2. Keaktifan ingatan, atlet sepak bola Pontianak di masa new normal tergolong pada 3 kategori yaitu sangat baik sebesar 50,5\%, baik sebesar 40,2\% dan cukup 9,3\%. Sedangkan untuk kategori kurang dan kurang sekali yaitu sebesar $0 \%$.

3. Keaktifan akal atlet atlet sepak bola Pontianak di masa new normal tergolong pada 4 kategori yaitu sangat baik sebesar 9,3\%, baik sebesar 55,7\%, cukup sebesar $32 \%$. Kategori kurang sebesar 3\% dan kategori kurang sekali sebesar $0 \%$.

4. Keaktifan emosi atlet atlet sepak bola Pontianak di masa new normal tergolong pada 3 kategori yaitu sangat baik adalah sebesar $51,2 \%$, kategori baik yaitu $81,4 \%$, sedangkan yang termasuk dalam kategori cukup $13,4 \%$, yang termasuk dalam kategori kurang dan kurang sekali berjumlah $0 \%$.

\section{DAFTAR PUSTAKA}

Ahmad, H., \& Yahmun, Y. (2017). Pemahaman tentang Budaya Supporter Sepakbola (Kajian Fenomenologi Berdasarkan Kasus Supporter Sepakbola Aremania Malang).

Paradigma: Jurnal Filsafat, Sains, Teknologi, Dan Sosial Budaya, 23(1), 3346. https://doi.org/10.33503/paradigma.v23i1.36 7

Aji, R. B. (2016). Sepak Bola dan Eksistensi Bangsa Dalam Olimpiade Masa Orde Lama (1945-1966). MOZAIK HUMANIORA, 16(1), 92-103.

Cendra, R. (2016). Pengaruh Menonton Pertandingan Sepakbola Di Televisi Terhadap Perilaku Sosial Anak Dalam Bermain Sepakbola. Journal Sport Area, 1(1), 71-78. https://doi.org/10.25299/sportarea.2016.vol1 (1). 380

Deddy Whinata Kardiyanto. (2020). Dampak pandemi covid-19 terhadap event olahraga dan sosial ekonomi masyarakat. Seminar Nasional Fakultas Ilmu Kesehatan Dan Sains, 1(1), 98-100.

Effendi, H. (2016). Peranan Psikologi Olahraga Dalam Meningkatkan Prestasi Atlet. Nusantara (Jurnal Ilmu Pengetahuan Sosial, 1(1), 23-30.

Ilham Setyawan. (2011). Manajemen Sekolah Sepakbola (SSB) Bhaladika Semarang Tahun 2009. Doctoral Dissertation, Universitas Negeri Semarang.

Komarudin, \& Risqi, F. (2020). Tingkat kepercayaan diri, kohesivitas, dan kecerdasan emosi siswa Kelas Khusus Olahraga cabang olahraga sepakbola. Pendidikan Jasmani Indonesia, 16(1), 1-8.

Moleong, L. J. (2017). Metodologi Penelitian Kualitatif (Edisi Revisi). In PT. Remaja Rosda Karya.

Muskanan, K. (2015). Analisis Motivasi Berprestasi Atlet Pusat Pendidikan dan Latihan Olahraga Pelajar Provinsi Nusa Tenggara Timur. JKAP (Jurnal Kebijakan 
Dan Administrasi Publik), 19(2), 105-112. https://doi.org/10.22146/jkap.7608

Nikmah, E. H., Fatchan, A., \& Wirahayu, Y. A. (2016). Model Pembelajaran Student Teams Achievement Divisions (STAD), Keaktifan dan Hasil Belajar Siswa. Jurnal Pendidikan Geografi, 3(3), 1-17.

Prastyo, N. E., Saichudin, S., \& Kinanti, R. G. (2014). Pola Hidup Sehat Dan Tingkat Kebugaran Jasmani Pada Siswa Peserta Kegiatan Ekstrakurikuler Sepakbola SMA Negeri. Jurnal Sport Science, 4(1), 49-53.

Purnamasari, A. D., Nurseto, F., \& Tarigan, H. (2013). Hubungan antara kecerdasan emosional dengan hasil belajar keterampilan dasar sepakbola siswa. JUPE (Jurnal Penjaskesrek), 1(3), 12-19.

Rahman, K. S., \& Padli. (2020). Tinjauan Kemampuan Teknik Dasar Sepakbola. Jurnal Patriot, 2(2), 369-379.

Ramlah, Firmansyah, D., \& Zubair, H. (2014). Pengaruh Gaya Belajar dan Keaktifan Siswa Terhadap Prestasi Belajar Matematika ( Survey Pada SMP Negeri di Kecamatan Klari Kabupaten Karawang). Jurnal Ilmiah Solusi, 1(3), 68-75.

Sinatriyo, D., Kusuma, I. J., Festiawan, R., Kusnandar, K., \& Heza, F. N. (2020). Keseimbangan dan Kelentukan Pergelangan Kaki: Bagaimanakah Korelasinya dengan Kemampuan Shooting Sepakbola? Media Ilmu Keolahragaan Indonesia, 10(1), 6-12. https://doi.org/10.15294/miki.v10i1.23943

Sugiyono. (2018). Metode Penelitian Kuantitatif,Kualitatif dan R\&D. In $\mathrm{Ke}-26$. Alfabeta.

Suharsimi, A. (2010). Prosedur Penelitian : Suatu Pendekatan Praktik (Edisi Revisi). In Rineka Cipta.

https://doi.org/10.1017/CBO978110741532 4.004

Sumarno, S., \& Irianto, D. P. (2019). Evaluasi Manajemen Klub Perserikatan Sepakbola Indonesia Mataram (PSIM) Yogyakarta. Jurnal Keolahragaan, 7(2), 104-115. https://doi.org/10.21831/jk.v7i2.26395
Supriyanto, E. (2017). Hubungan Kematangan Emosi dan Agresifitas Pada Pemain Sepak Bola Remaja Akhir. Jurnal Psikologi, 10(2), 183-191.

Tim Komunikasi Publik Gugus Tugas Nasional. (2020). Tetap Berolahraga di Tengah Pandemi COVID-19. Satuan Tugas Penanganan Covid-19, 1.

Tri Kusuma, A. (2017). Kreolisasi dalam Kultur Suporter Sepakbola (Mimikri, Hibriditas dan Glokalisasi Brigata Curva Sud PSS Sleman). Jurnal Komunikasi, 11(2), 117-136. https://doi.org/10.20885/komunikasi.vol11.i ss2.art2

Wibowo, A. T., Syafitri, A., \& Iwandana, D. T. (2019). Psychological Characteristics of PSIM Yogyakarta Players in Wading the League 2 Soccer Competition in 2019/2020. Quality in Sport, 9(11), 217-225. https://doi.org/10.12775/qs.2019.018 